International Research Journal of Engineering, IT \& Scientific Research
Available online at https://sloap.org/journals/index.php/irjeis/
Vol. 4 No. 6, November 2018, pages: $10 \sim 32$
ISSN: 2454-2261
https://sloap.org/journals/index.php/irjeis/article/view/331

\title{
Reduction of Levels Postprandial Blood Glucose on Medium Intensity Physical Exercise in Intervals and Continues
}

\author{
Akhmad Fathoni ${ }^{\text {a }}$ \\ N. Adiputra ${ }^{b}$ \\ J. Alex Pangkahila ${ }^{c}$ \\ I Putu Gede Adiatmika ${ }^{d}$
}

Article history:

Received: 4 April 2018

Accepted: 30 September 2018

Published: 16 October 2018

\section{Keywords:}

Continues;

Intervals;

Levels postprandial blood

glucose;

Medium intensity physical

exercise;

Reduction;

\section{Author correspondence:}

Akhmad Fathoni,

POLTEKKES KEMENKES Mataram at Jln. Prabu Rangkasari Dasan Cermin Mataram

Ph. +62370 631160, Fax. +62370621383

Email address: afathoni72@gmail.com

\begin{abstract}
The research was intended to Proving short-term physical exercise lowers blood glucose on patients with diabetes mellitus. Proving long-term physical exercise lowers blood glucose on patients with diabetes mellitus. Proving long-term physical exercise further lowers blood glucose compared to shortterm physical exercise on patients with diabetes mellitus. From the discussion described earlier, the following conclusions can be drawn included (1) Light intensity physical exercise for 20 minutes can reduce blood glucose in diabetes mellitus patients immediately after exercise and 1 hour after exercise. (2) 10 minutes of moderate intensity physical exercise can reduce blood glucose immediately after 10 minutes of exercise and 1 hour after exercise. (3) There is no difference in blood glucose reduction in 20 minutes duration light exercise with 10 minutes duration exercise in people with diabetes mellitus.
\end{abstract}

2454-2261 ${ }^{\circledR}$ Copyright 2018. The Author. This is an open-access article under the CC BY-SA license (https://creativecommons.org/licenses/by-sa/4.0/) All rights reserved.

\section{Introduction}

On patients with diabetes mellitus, a metabolic change that causes hyperglycemia (blood glucose $>126 \mathrm{mg} / \mathrm{dl}$ ) is caused by glucose transport across the reduced cell membrane, reduced glycogenesis and increased glycolysis (Bleving, 2000). One of the consequences or complications that occur in patients with diabetes mellitus is the occurrence of hyperglycemia that can eventually lead to coma. If blood sugar levels are continuously high and

${ }^{a}$ Udayana University, Indonesia

${ }^{\mathrm{b}}$ Udayana University, Indonesia

c Udayana University, Indonesia

${ }^{\mathrm{d}}$ Udayana University, Indonesia 
uncontrollable, complications may occur in all blood vessels such as blood vessels of the brain (stroke), eye blood vessels (blindness), systemic blood vessels (hypertension), coronary arteries with coronary heart disease, renal blood vessels (kidney failure), can also occur injuries that are difficult to heal (gangrene) (Nuriyasa et al., 2018).

Diabetes mellitus can be controlled by diet, exercise, and anti-diabetic treatment. Control of diabetes mellitus is with exercise or physical exercise (Soeparman, 1991). Exercise will increase glucose uptake by contracting the skeletal muscle (Goodyer, 1999). Exercise can regulate blood glucose levels through increased insulin regulation as a result of the exercise process. In the exercise, it will stimulate GLUT4 translocation that does not cause GTP-binding protein as it does in stimulation by insulin (Youngren, 2003). The translocations caused by exercise to date have not been clear, but can be explained by the release of $\mathrm{Ca}$ ions from the sarcoplasmic reticulum causing the contraction process. This $\mathrm{Ca}$ ion will activate the serine kinase PKC in hyper synthesizing GLUT4 whose mechanism is unknown (Youngren, 2003), has occurred in short-term exercise or after long-term exercise.

To reduce glucose levels in the blood then given the appropriate exercise in people with diabetes mellitus by looking at the combination of the state of the patient with the dose of exercise. The dose of exercise according to (Fox, EL 1993) includes the intensity, duration, frequency, and type of exercise. In this study will compare the differences. There is three question discussed in the present study included (1) Do short-term physical exercise can lower blood glucose in people with diabetes mellitus? (2) Will long-term physical exercise decrease blood glucose in people with diabetes mellitus? (3) Does long-term physical exercise lower blood glucose than a short-term physical exercise in people with diabetes mellitus?

\section{Literature review}

A literature review is more directed to the effect of physical exercise on glucose metabolism. Factors that contribute include the factors in skeletal muscle in physical exercise and the influence of hormones involved in glucose metabolism, especially during exercise after postprandial. There is a different understanding of physical activity (physical activity), physical exercise (physical exercise) and physical training (physical training). Physical activity is all forms of muscle movement, physical exercise is a specific physical activity, and physical training is a repetitive, systematic, and purposeful exercise (Leaf, 1991 in Harjanto, 2003). Component (dose) of physical exercise consists of 1) intensity, 2) frequency and rhythm, 3) duration and 4) mode or type of exercise (e.g. interval and continuous) (Wilmore, 1994; Harjanto, 2003). The intensity of the exercise is the most important factor in the principle of loading (Fox, 1993). The intensity of physical exercise is related to maximal aerobic strength (Wilmore, 1994). Physical exercise is mild, moderate or severe for the maximum capacity of aerobic physical exercise such as the person is called maximal oxygen uptake (VO2 max). Maximal oxygen uptake (VO2 max) is oxygen uptake during the maximum physical exercise (Janssen, 1987). Maximal oxygen uptake is determined by age, body size, and gender. In men $20 \%$ higher than women and at age 20 is the peak (Fox, 1999).

Based on VO2 max, the intensity of physical exercise can be divided into 1) low-intensity physical exercise (approximately less than 45\% VO2 max); 2) moderate intensity physical exercise (about 50-70\% VO2 max); and 3) high-intensity physical exercise about more than 80\% VO2max) (Yaspelkis, 1993; Fox, 1999). The determination of exercise intensity can be done by pulse method and conceptual method on the anaerobic threshold value. (Fox, 1993). Pulse method is an indirect way to estimate the use of oxygen by the body. Maximum heart rate (HRmax) or maximum pulse is achieved before maximum oxygen consumption is achieved, for example, $70 \%$ of maximal pulse equals $65 \%$ of maximal aerobic capacity (65\% VO2max). The higher the pulse rate, the higher the physical exercise intensity. The maximum pulse can be determined from the calculation of 220 minus age (Fox, 1999).

Anaerobic threshold method is the intensity of the workload through the increase of anaerobic metabolism which can be known through increased accumulation of lactic acid in the blood and skeletal muscle (Fox, 1993). Differences in pulse method and the anaerobic threshold value method include that the pulse method mainly assesses the cardiovascular system and the anaerobic threshold value method assesses the metabolic system especially the skeletal muscle. An anaerobic threshold method is involving measurement of lactic acid. Levels of lactic acid 4 $\mathrm{mmol} / \mathrm{L}$, will be obtained on the average pulse rate of $91 \%$ maximum pulse, while at $80 \%$ maximum pulse, only $55 \%$ of subjects will perform at that dose (Fox, 1993).

Fathoni, A., Adiputra, N., Pangkahila, J. A., \& Adiatmika, I. P. G. (2018). Reduction of levels postprandial blood glucose on medium intensity physical exercise in intervals and continues. International Research Journal of Engineering, IT \& Scientific Research, 4(6), 10-32. https://doi.org/10.21744/irjeis.v4n6.331 


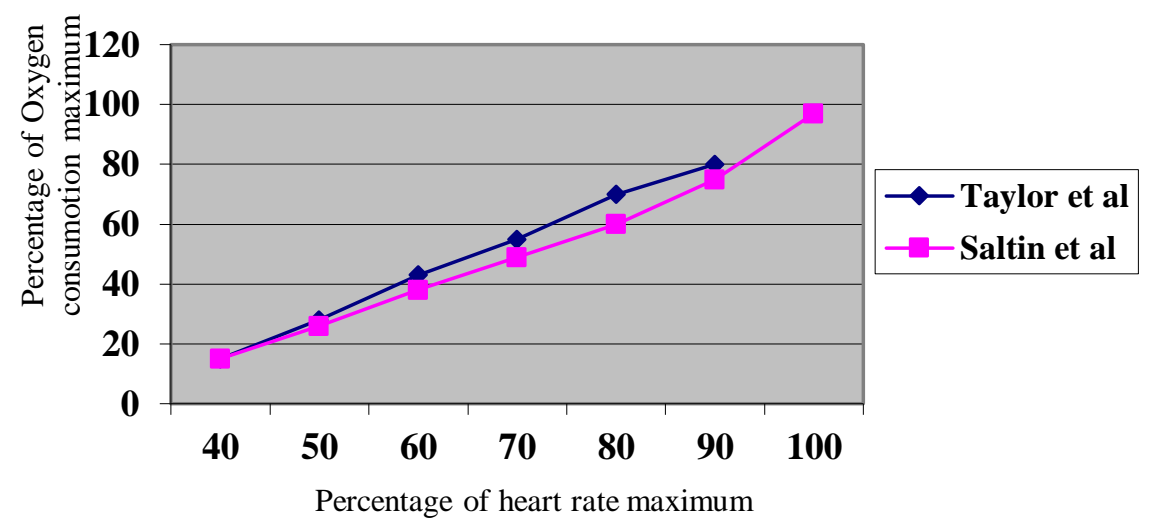

Figure 1. The relationship between pulse rate and maximal oxygen consumption (VO2 max)

Data from Saltin (1968) ( $\square$ ) and Taylor (1969) $(\bullet)$ were quoted from Fox (1993). The ideal value is illustrated by dashed lines (Fox, 1993). Physical exercise interval means repetition (repetition of physical exercise) with short to moderate duration and the repetition of the physical exercise of this interval consists of the working and resting phases (Brooks, 1985, Fox, 1993). Physical exercise of the interval may increase the ATP-PC energy system in the muscle, which during rest periods of ATP-PC synthesis can take place so that it can be used as energy for the next period of exercise, and anaerobic glycolytic with less lactic acid production to reduce fatigue (Brook, 1985, Fox, 1993).

In the interval physical exercise there is the term work interval which means phase while doing physical exercise with moderate intensity, and relief interval that is the rest phase which can be done by 1) performing mild activity e.g. rest relief, 2) doing light physical exercise work-relief, and 3) a combination of the two (Fox, 1993). Rest relief intervals are used when the expected ATP-PC system can be synthesized back through the anaerobic system. Workrelief intervals will use the lactic acid system although the buildup is not too high (Fox, 1993). Work-relief ratios (the ratio of break work) are used to find out the comparison between the physical exercise phase and the resting phase. For example, 11/2 which means the resting phase is $1 / 2$ times the exercise phase, $1: 1$ which means the resting phase is equal to the training phase, and 1: 2 which means the resting phase is 2 times longer than the exercise phase (Fox, 1993). Continuous physical exercise is not obtained repetition or repetition and there is no period of rest. Continuous physical exercise is generally a submaximal intensity and is more suitable (aerobic) then the energy system used increasingly aerobic (Noble, 1986).

\section{Materials and Methods}

\section{Research Design}

The research to be carried out is laboratory experimental research and a cross-sectional study with one-group pretest-posttest design. (Zainuddin, 2000) The research design scheme is the research is as follows:

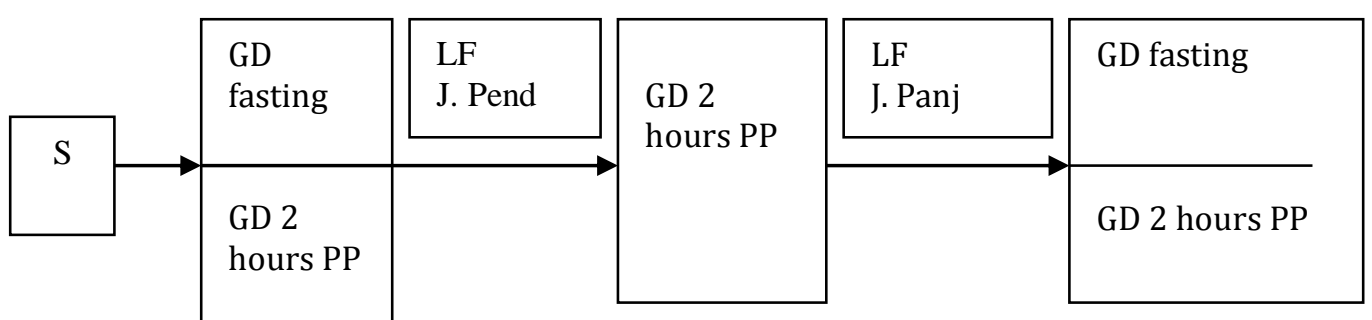

Figure 1. The research design scheme 
Information:

$\begin{array}{ll}\mathrm{S} & =\text { Sample } \\ \text { GD Fasting } & =\text { Fasting Blood Sugar taken before physical exercise. } \\ \text { GD 2 Hours PP } & =\text { Blood Sugar 2 hours postprandial before physical exercise } \\ \text { LF J. Pend } & \text { = Short-Term Physical Exercise } \\ \text { GD 2 hours PP } & =\text { Blood Sugar } 2 \text { hours postprandial after short-term physical exercise. } \\ \text { LF J. Panj } & =\text { Long Term Physical Exercise } \\ \text { GD Fasting } & =\text { Fasting Blood Sugar after long-term exercise } \\ \text { GD 2 hours PP } & =2 \text { hours postprandial Blood Sugar after long-term physical exercise. }\end{array}$

\section{Population, sample, sample size, and sampling technique}

The population in this study is people with diabetes mellitus. Patients selected are those who suffered type 2 diabetes mellitus at the General Hospital of Mataram. Preferred patients are women 40-60 years old, not contraindicated for physical exercise, and willing to sign a consent letter as a trial person in this study. Patients who meet the above criteria the opportunity to become a member of the research sample (try people). The determination of the sample size refers to a study of the effect of sucrose and glucose prior to exercise on blood glucose levels after exercise (Wiriawan, 2000) using the Higgins (1985) formula. From the calculation results obtained for 7 for each group, the sampling technique is a simple randomized by lottery method.

Research variable Research variables include independent variables, dependent variables, control variables, moderator variables. Independent variables (Short-term physical exercise, Long-term physical exercise), the dependent variable on this study was a decrease in blood glucose levels after physical. Moderator variables in this study were height, weight, fasting blood glucose, and postprandial blood glucose levels. The control variables in this study were gender, age, status, health, examination environment, and examination procedures.

Physical exercise performed by blood glucose measurement immediately after physical exercise with moderate intensity, frequency 5 times a week, duration 20 minutes interval conducted is physical exercise with intensity $70 \%$ 80\% Hrmax (Cantu, 1987: Fox, 1993). Physical exercise performed by blood glucose measurement one week after exercising with moderate intensity, frequency 5 times a week, duration 20 minutes, intensity $70 \%-80 \% \mathrm{Hr}$ max (equivalent premises 50\% -60\% VO max) (Cantu, 1987: Fox, 1993).

\section{Decreased postprandial blood glucose levels}

The decrease in postprandial blood glucose levels is determined from the difference in the magnitude of the decrease in blood glucose levels taken on the first day immediately after physical exercise by one week immediately after physical exercise. Blood glucose examination performed by GOD-PAP method included $\mathrm{Hr}$ max or molar pulse is determined by the formula 220 minus age (years) (Fox, 993). The meaning of sex in this study is female sex in accordance with the identity data taken from the General Hospital of Mataram Region. Age of trial people is 50-60 years based on identity data from Poly Disease in Mataram Hospital.

The health status is the health status of a reasonable person for moderate intensity exercise for 20 minutes accompanied by 2 -minute heating determined from the interview (anamnesis) and physical examination. The environmental examination is the environment of the examination room at the Polytechnic Laboratory of Mataram Health at a temperature of $21^{\circ} \mathrm{C}$. The checking procedure is a physical exercise procedure and examination of the same variables for all members of the try-out group.

\section{Materials and Instruments Research}

The unit of analysis for the examination of dependent variables is blood for examination of blood glucose levels. Materials for examination of blood glucose levels, Materials needed are TCA (Tri Chloro Acetic Acid), glucose reagent, glucose standard $100 \mathrm{mg} / \mathrm{dl}$, aquadest. The instruments used in this research are:

a. Heart rate monitor (Polar)

b. Stop Watch (Polar)

c. Tensimeter

Fathoni, A., Adiputra, N., Pangkahila, J. A., \& Adiatmika, I. P. G. (2018). Reduction of levels postprandial blood glucose on medium intensity physical exercise in intervals and continues. International Research Journal of Engineering, IT \& Scientific Research, 4(6), 10-32. https://doi.org/10.21744/irjeis.v4n6.331 

d. Stethoscope
e. Metronome
f. Spectrophotometer
g. Measures of height and weight.

\section{Location and Time of Research}

Physical exercise and examination of blood glucose level are done at Health Polytechnic Laboratory of Mataram Kesehatan street No. V/10 Mataram, the examination for the study was conducted in May 2005.

\section{Data Collection and Collection Procedures}

Distribution of groups of trying people

a) Group of people trying to do data collection on the poly disease in Mataram

b) hospital.

c) Then checked the fasting blood sugar and blood sugar PP 2ja to determine the patient is experiencing Diabetes mellitus (fasting blood sugar> $126 \mathrm{mg} / \mathrm{dl}$, blood sugar 2 hours PP> $200 \mathrm{mg} / \mathrm{dl}$ ). Besides that, the examination of BBR (relative weight) to determine the needs of caloric patients and examination Hate rate to determine the type of exercise given.

d) Before the physical exercise the patient is given to eat bread/rice and white water adjusted for BBR, if the normal weight is given calories $30 \mathrm{cal} / \mathrm{kg} \mathrm{BW}$, if more weight is given calories $20 \mathrm{cal} / \mathrm{kg} \mathrm{BW}$ and if the fat is given $15 \mathrm{cal} / \mathrm{kg} \mathrm{BW}$, if lean is given $40-60 \mathrm{cal} / \mathrm{kg} \mathrm{BW}$.

e) Then on the following day after being given calorie consumption and rest for one and a half hours then performed the physical exercise with a moderate intensity of $70 \%-80 \%$ (equivalent to 50-60 Vo max), duration 20 minutes, one-time frequency, type of physical exercise feet as far as $1,5 \mathrm{~km}$.

f) Immediately after physical exercise, blood sugar is extracted into preliminary data to determine the decrease in blood glucose levels in the patient Diabetes mellitus.

g) On the next day, the physical training is given in the same way as above and done for five times a week.

h) On the fifth day, the patient is told to start fasting from $24.00-08.00$ then take the fasting blood sugar, after it is given calorie fulfillment and rest for one and a half hours, then performed physical exercises as above and immediately after physical exercise performed blood sugar check

i) During physical exercise, it is not advisable to consume drugs.

Medical examination Health checks are conducted with interviews and physical examinations, namely vital sign checks and inspection examination, palpation, and auscultation. Blood sampling is performed on fasting conditions, 2 hours postprandial and 2 postprandial hours immediately after physical exercise.

\section{Data analysis}

Data analysis performed with SPSS program include:

a. Descriptive statistical test of pretest and posttest data to know variable characteristic.

b. Test the distribution normality.

c. Homogeneity tests were performed to determine whether variance conditions before treatment were similar across groups.

d. Test the correlation to know the relationship between variables.

e. Test $t$ to find out whether there is a decrease in blood glucose levels in short-term exercise and long-term exercise.

f. Test the adequacy of the sample to know that the sample size in this study has been sufficient or not. 


\section{Results and Discussions}

\subsection{Results}

Data obtained from the results of research in form of body weight of people trying $(\mathrm{kg})$, height (cm) and fasting blood sugar levels (mg/dl), blood sugar 2 (two) hours postprandial, 20 after exercise (20 minutes postprandial), 10 minutes after exercise (10 minutes postprandial), 60 minutes after exercise in $\mathrm{mg} / \mathrm{dl}$. Data analysis was carried out with descriptive analysis, distribution normality test, homogeneity test, correlation test, and Manova test with a significance level of 5\% and all data processed with SPSS 10.0 program.

\section{Descriptive Data}

In this study, the data taken included variables namely independent variables, dependent variables, and moderator variables. All of the data were analyzed statistically to obtain an overview of the distribution, summarization, and processing of data. The results of the descriptive analysis moderator variables can be seen in Table 1 and the dependent variable can be seen in Table 2 below. The results of the analysis of the full variables can be seen in the attachment.

Table 1

Average value and SD Variable BB $(\mathrm{kg}), \mathrm{TB}(\mathrm{cm})$, Pulse (permanent)

\begin{tabular}{|c|c|c|c|c|c|}
\hline Group & & & Weight body & Height Body & Pulse \\
\hline Light $\quad$ Training & 20 & Mean & 49,20 & 163,40 & 86,50 \\
\hline minutes & & Std. & 4,47 & 4,33 & 1,96 \\
\hline & & Deviation & & & \\
\hline & & $\mathrm{N}$ & 10 & 10 & 10 \\
\hline \multirow{4}{*}{$\begin{array}{l}\text { Medium } \\
\text { minutes }\end{array}$} & 10 & Mean & 49,40 & 163,90 & 96,10 \\
\hline & & Std. & 5,52 & 3,90 & 3,51 \\
\hline & & Deviation & & & \\
\hline & & $\mathrm{N}$ & 10 & 10 & 10 \\
\hline
\end{tabular}

From the data above the mean value for body weight and standard deviation in light training duration of 20 minutes

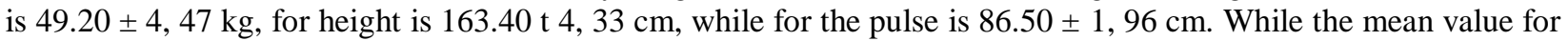
body weight at moderate exercise duration of 10 minutes is $49.40 \pm 5.52 \mathrm{~kg}$ for height $163.90 \pm 3.90 \mathrm{~cm}$ and for the pulse is $96.10 \pm 3.51$ per minute.

Table 2

Mean and SD variables for blood sugar $(\mathrm{mg} / \mathrm{dl})$ in all groups

\begin{tabular}{|c|c|c|c|c|c|}
\hline \multicolumn{2}{|l|}{ Group } & $\begin{array}{l}\text { blood sugar } \\
\text { fasting }\end{array}$ & $\begin{array}{c}\text { blood sugar } \\
\text { J PP }\end{array}$ & $\begin{array}{l}\text { blood sugar } \\
20 \mathrm{M} \mathrm{PL}\end{array}$ & $\begin{array}{l}\text { blood sugar } \\
60 \mathrm{M} \mathrm{PL}\end{array}$ \\
\hline Light training & Mean & 145,10 & 200,30 & 170,40 & 158,30 \\
\hline minutes & Std. Deviation & 9,01 & 39,47 & 24,80 & 19,56 \\
\hline & $\mathrm{N}$ & 10 & 10 & 10 & 10 \\
\hline Medium training 10 & Mean & 149,00 & 202,90 & 175,80 & 160,70 \\
\hline minutes & Std. Deviation & 11,07 & 34,20 & 26,08 & 15,00 \\
\hline & $\mathrm{N}$ & 10 & 10 & 10 & 10 \\
\hline
\end{tabular}

From the data above in light intensity training for 20 minutes, the mean of fasting blood mean $145.10 \pm 9.01 \mathrm{mg} / \mathrm{dl}$, blood sugar 2 hours post prandial $200.30 \pm 39.47 \mathrm{mg} / \mathrm{dl}$, blood sugar 20 minutes after exercise was $170.40 \pm 24.80$ $\mathrm{mg} / \mathrm{dl}$, blood sugar 60 minutes after exercise $158.30 \pm 19.56 \mathrm{mg} / \mathrm{dl}$. From the data above on 10-minutes medium

Fathoni, A., Adiputra, N., Pangkahila, J. A., \& Adiatmika, I. P. G. (2018). Reduction of levels postprandial blood glucose on medium intensity physical exercise in intervals and continues. International Research Journal of Engineering, IT \& Scientific Research, 4(6), 10-32. https://doi.org/10.21744/irjeis.v4n6.331 
intensity exercise, the mean fasting blood sugar was $149.00 \pm 11.07 \mathrm{mg} / \mathrm{dl}$, blood sugar 2 hours post prandial was $202.30 \pm 34.20 \mathrm{mg} / \mathrm{dl}$, blood sugar 20 minutes after exercise of $175.80 \pm 26.08 \mathrm{mg} / \mathrm{dl}$, blood sugar 60 minutes after exercise amounted to $160.70 \pm 15.00 \mathrm{mg} / \mathrm{dl}$.

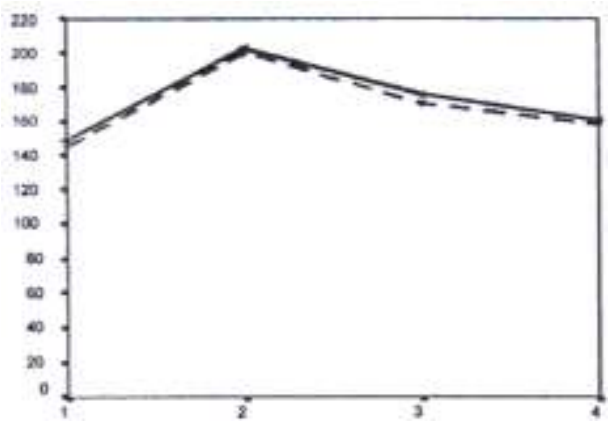

Figure 2. The decline in blood glucose graph in both groups (blood sugar action)

Table 3

Average value and SD Variable BB $(\mathrm{kg}), \mathrm{TB}(\mathrm{cm})$, Pulse (permanent)

\begin{tabular}{llrrr}
\hline Group & Mean & $\begin{array}{c}\text { Decrease in blood } \\
\text { sugar-20 }\end{array}$ & $\begin{array}{c}\text { Decrease in } \\
\text { blood sugar-60 }\end{array}$ & $\begin{array}{c}\text { Decrease in blood } \\
\text { sugar-20-60 }\end{array}$ \\
Light training & 20 & 29,9000 & 42,0000 & 12,1000 \\
minutes & Std. Deviation & 25,3966 & 24,0000 & 8,1438 \\
& N & 10 & 10 & 10 \\
Medium training & Mean & 27,1000 & 42,2000 & 15,1000 \\
10 minutes & Std. Deviation & 12,4137 & 21,6887 & 15,5810 \\
& $\mathrm{~N}$ & 10 & 10 & 10 \\
\hline
\end{tabular}

From the data above 20 minutes of light physical exercise, the average blood glucose reduction difference between 2 hours postprandial and 20 minutes after exercise was $29.9000 \pm 25.3966 \mathrm{mg} / \mathrm{dl}$, the mean blood glucose reduction difference between 2 hours postprandial and 60 minutes after exercise was 42,0000 $\pm 24,000 \mathrm{mg} / \mathrm{dl}$, the mean decrease in blood glucose difference between 20 minutes after exercise with 60 minutes after exercise was 12,1000 \pm $8,1438 \mathrm{mg} / \mathrm{dl}$.

From the above data on a 10-minute moderate intensity physical exercise, the average blood glucose reduction difference between 2 hours postprandial and 20 minutes after exercise was $27.1000 \pm 12.4137 \mathrm{mg} / \mathrm{dl}$, the mean blood glucose reduction difference between 2 hours postprandial and 60 minutes after exercise was $42.2000 \pm 21.6887$ $\mathrm{mg} / \mathrm{dl}$, the average decrease in blood glucose difference between 20 minutes after exercise with 60 minutes after exercise was $15.1000 \pm 15.5810 \mathrm{mg} / \mathrm{dl}$.

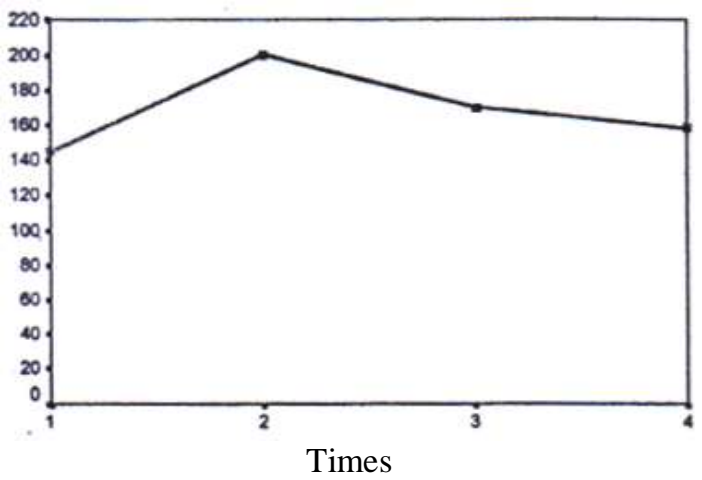

Figure 3. Graph of decreased blood glucose in moderate exercise group duration of 20 minutes (Group 1, Light Exercise 20 Minutes) 


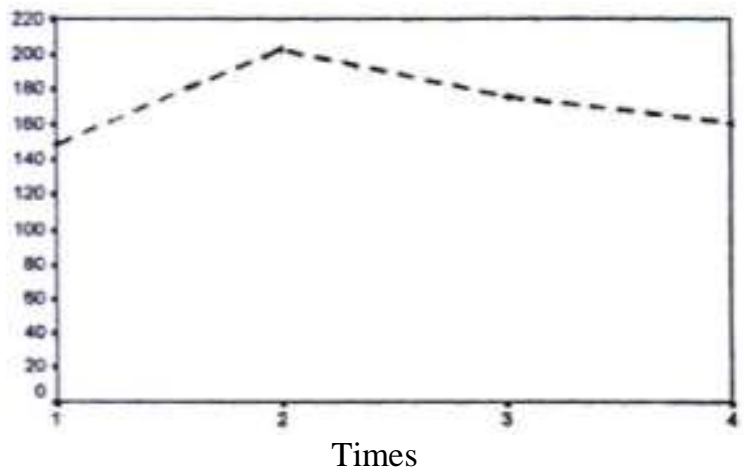

Figure 4. Graph of decreased blood glucose in moderate exercise group duration of 10 minutes

(Group 2. Medical Training)

\section{Normality Test}

To find out whether the data to be analyzed is normally distributed or not to determine to the next statistical test stage, normality tests are carried out. The results of the Kolmogorov-Smirnov normality test were carried out in the treatment group, namely the group on 20 minutes of light intensity physical exercise with 10 minutes of moderate intensity physical exercise which referred to the price value of $\mathrm{p}>0.05$ means normal distribution.

Table 4

Test the normality of blood sugar values in the 20-minute light exercise group One-sample Kolmogorov-Smirnov Test C

\begin{tabular}{llrrrr}
\hline & & Faded Fasting & Faded 2 J PP & Faded 20 M PL & Faded 60 M PL \\
\hline N & & 10 & 10 & 10 & 10 \\
Normal Parameters & Mean & 145,10 & 200,30 & 170,40 & 158,30 \\
& Std. Deviation & 9,01 & 39,47 & 24,80 & 19,56 \\
Most Extreme & Absolute &, 204 &, 203 &, 248 &, 201 \\
Differences & Positive &, 204 &, 203 &, 248 &, 201 \\
& Negative &,- 115 &,- 142 &,- 173 &, 138 \\
Kolmogorop_Smirnov Z & &, 646 &, 642 &, 783 &, 635 \\
Asymp. Sig. (2-tailed) & &, 797 &, 804 &, 572 &, 815 \\
\hline
\end{tabular}

a. Test distribution is Normal.

b. Calculated from data.

c. Group $=20$ Minutes Light Training

From the data above shows that the normality test for fasting blood sugar $(\mathrm{p}=0.797)$, blood sugar 2 hours postprandial $(\mathrm{p}=0.804)$, blood sugar 20 minutes after exercise $(\mathrm{p}=0.572)$ and 60 minutes $(\mathrm{p}=0.815)$ and see the significant value which refers to $\mathrm{p}>0.05$ then the data above is normally distributed.

Fathoni, A., Adiputra, N., Pangkahila, J. A., \& Adiatmika, I. P. G. (2018). Reduction of levels postprandial blood glucose on medium intensity physical exercise in intervals and continues. International Research Journal of Engineering, IT \& Scientific Research, 4(6), 10-32. https://doi.org/10.21744/irjeis.v4n6.331 
Table 5

Normality value test decreased blood sugar in the 20-minute light exercise group.

One-sample Kolmogorov-Smirnov Test

\begin{tabular}{|c|c|c|c|c|}
\hline & & $\begin{array}{c}\text { Reduction of } \\
\text { blood sugar-20 }\end{array}$ & $\begin{array}{c}\text { Reduction of } \\
\text { blood sugar- } 60\end{array}$ & $\begin{array}{c}\text { Reduction of blood } \\
\text { sugar20-60 }\end{array}$ \\
\hline $\mathrm{N}$ & & 10 & 10 & 10 \\
\hline \multirow[t]{2}{*}{ Normal Parameters } & Mean & 29,9000 & 42,0000 & 12,1000 \\
\hline & Std. Deviation & 25,3966 & 24,0000 & 8,1438 \\
\hline Most Extreme & Absolute & ,290 &, 317 & ,202 \\
\hline \multirow[t]{2}{*}{ Differences } & Positive & 290 &, 317 & ,202 \\
\hline & Negative &,- 228 &,- 191 &,- 132 \\
\hline Kolmogorop_Smirnov Z & & ,917 & 1,004 & ,638 \\
\hline Asymp. Sig. (2-tailed) & & 370 & ,266 & ,810 \\
\hline
\end{tabular}

a) Test distribution is Normal.

b) Calculated from data.

c) Group = 20 minutes light training

From the above data on light intensity physical exercise for 20 minutes, the average blood glucose reduction difference between 2 hours postprandial and 20 minutes after exercise was $29.9000 \pm 25.3966 \mathrm{mg} / \mathrm{dl}$, the average blood glucose reduction difference between 2 hours postprandial and 60 minutes after exercise was $42,0000 \pm$ $24,0000 \mathrm{mg} / \mathrm{dl}$, the mean reduction in blood glucose difference between 20 minutes after exercise with 60 minutes after exercise was $12,1000 \pm 8,1438 \mathrm{mgl}$, and saw the significant value referring to $\mathrm{p}>005$, the data above is normally distributed.

Table 6

The normality test of blood sugar values in the moderate exercise group was 20 minutes One-sample Kolmogorov-Smirnov Test ${ }^{\mathrm{C}}$

\begin{tabular}{llrrrr}
\hline & & Blood sugar & Blood sugar & Blood sugar 20 & \multicolumn{2}{c}{ Blood sugar 60 } \\
& & \multicolumn{1}{c}{ M PL } & \multicolumn{1}{c}{ M PL } \\
\hline N & & 10 & 10 & 10 & 10 \\
Normal Parameters & Mean & 149,00 & 202,90 & 175,80 & 160,70 \\
& Std. Deviation & 11,07 & 34,20 & 26,08 & 15,00 \\
Most Extreme & Absolute &, 128 &, 334 &, 306 &, 219 \\
Differences & Positive &, 128 &, 334 &, 306 &, 219 \\
& Negative &,- 126 &,- 183 &,- 272 &,- 112 \\
Kolmogorop_Smirnov Z & &, 406 & 1,056 &, 968 &, 691 \\
Asymp. Sig. (2-tailed) & &, 997 &, 215 &, 306 &, 726 \\
\hline
\end{tabular}

a) Test distribution is Normal.

b) Calculated from data.

c) Group = 20 Minutes Light Training

From the data above shows that the normality test for fasting blood sugar $(\mathrm{p}=0.997)$, blood sugar 2 hours postprandial $(\mathrm{p}=0.215)$, blood sugar 20 minutes after exercise $(\mathrm{p}=0.306)$ and 60 minutes after exercise $(\mathrm{p}=0.726)$ and see the significant value which refers to $\mathrm{p}>0.05$ then the data above is normally distributed. 
Table 7

The normality test of blood sugar values in the moderate exercise group was 20 minutes. One-sample Kolmogorov-Smirnov Test ${ }^{\mathrm{C}}$

\begin{tabular}{|c|c|c|c|c|}
\hline & & $\begin{array}{c}\text { Decrease in } \\
\text { blood sugar-20 }\end{array}$ & $\begin{array}{c}\text { Decrease in } \\
\text { blood sugar-60 }\end{array}$ & $\begin{array}{l}\text { Decrease in blood } \\
\text { sugar-20-60 }\end{array}$ \\
\hline $\mathrm{N}$ & & 10 & 10 & 10 \\
\hline \multirow[t]{2}{*}{ Normal Parameters } & Mean & 27,1000 & 42,2000 & 15,1000 \\
\hline & Std. Deviation & 12,4137 & 21,6887 & 15,5810 \\
\hline Most Extreme & Absolute & ,113 & ,313 & ,238 \\
\hline \multirow[t]{2}{*}{ Differences } & Positive &, 108 &, 313 & 229 \\
\hline & Negative &,- 113 &,- 228 &,- 238 \\
\hline Kolmogorop_Smirnov Z & & 358 & ,988 &, 756 \\
\hline Asymp. Sig. (2-tailed) & & 1,000 & 283 & 622 \\
\hline
\end{tabular}

a) Test distribution is Normal.

b) Calculated from data.

c) Group = 10 Minutes Light Training

From the above data on moderate intensity physical exercise 10 minutes duration seen significant values of blood glucose reduction difference between 2 hours postprandial with 20 minutes after exercise $(p=1,000)$, significant value of blood glucose reduction difference between 2 hours postprandial with 60 minutes after exercise $(p=0.283)$, a significant value of blood glucose deposition difference between 20 minutes after exercise with 60 minutes after exercise $(\mathrm{p}=0.622)$ and seeing the significant value referring to $\mathrm{p}>0.05$, the data above is normally distributed.

\section{Homogeneity Test}

Homogeneity test is carried out to find out that the variance in the initial conditions will occur after differences in exercise or treatment.

Table 8

Homogeneity Test, ANOVA Table

\begin{tabular}{llccccc}
\hline & & Sum Of Squares & Df & Mean Square & F & Sig. \\
\hline Weight body & Between Groups & 200 & 1 & 200 & .008 & .930 \\
& Within Groups & 454.000 & 18 & 25.222 & & \\
& Total & 454.200 & 19 & & & \multirow{2}{*}{ Height body } \\
& Between Groups & 1.250 & 1 & 1.250 & .074 & \\
& Within Groups & 305.300 & 18 & 16.961 & & \\
Total & 306.550 & 19 & & & .000 \\
& Between Groups & 460.800 & 1 & 460.800 & 57.045 & \\
& Within Groups & 145.400 & 18 & 8.078 & & \\
\hline
\end{tabular}

From the data above, it can be seen that the weight homogeneity $(\mathrm{p}=0.930)$, height $(\mathrm{P}=0.789) \mathrm{p}$-value is greater than 0.05 , the data above includes homogeneous data.

\section{Test of Difference in Changes in Blood Glucose}

The test results of different changes in blood glucose levels in a group of light intensity duration of 20 minutes and medium intensity duration of 10 minutes.

Fathoni, A., Adiputra, N., Pangkahila, J. A., \& Adiatmika, I. P. G. (2018). Reduction of levels postprandial blood glucose on medium intensity physical exercise in intervals and continues. International Research Journal of Engineering, IT \& Scientific Research, 4(6), 10-32. https://doi.org/10.21744/irjeis.v4n6.331 
Table 9

Average data and SD Blood glucose training is 20 minutes light (descriptive statistics)

\begin{tabular}{lccc}
\hline & Mean & Std. Deviation & $\mathrm{N}$ \\
\hline Fasting blood sugar & 145,10 & 9,01 & 10 \\
Fasting blood sugar 2 J & 200,30 & 39,47 & 10 \\
PP & & & 10 \\
Fasting blood sugar20 M & 170,40 & 24,80 & 10 \\
PL & 158,30 & 19,56 & \\
Fasting blood sugar 60 & & & \\
M PL
\end{tabular}

From the data above, it can be seen that the mean fasting blood sugar value in light exercise of 20 minutes duration is $145.10 \pm 9.01 \mathrm{mg} / \mathrm{dl}$, blood sugar 2 hours postprandia $1200.30 \pm 39.47 \mathrm{mg} / \mathrm{dl}$, blood sugar 20 minutes after exercise $170,40 \pm 24.80 \mathrm{mg} / \mathrm{dl}$, blood sugar 60 minutes after exercise $158.30 \pm 19.6 \mathrm{mg} / \mathrm{dl}$.

Table 10

Annova test results decrease blood sugar levels in 20 minutes light exercise (multivariate tests)

\begin{tabular}{lllllll}
\hline Effect & & Value & F & Hypothesis df & Error df & Sig. \\
\hline Time & Pillai's Trace &, 863 & $14,661^{\mathrm{a}}$ & 3,000 & 7,000 &, 002 \\
& Wilks'Lambda &, 137 & $14,661^{\mathrm{a}}$ & 3,000 & 7,000 &, 002 \\
& Hotelling's Trace & 6,283 & $14,661^{\mathrm{a}}$ & 3,000 & 7,000 &, 002 \\
& Roy's Largest Root & 6,283 & $14,661^{\mathrm{a}}$ & 3,000 & 7,000 &, 002 \\
\hline
\end{tabular}

a) Exact statistic

b) Design: Intercept

Within-Subjects Design: Time

Group $=20$ Minutes Light Training

From the data above shows that there is a significant value of $\mathrm{p}<0.05(\mathrm{p}=0.002)$ this means that there is a significant difference in the occurrence of changes in blood glucose in the treatment group.

Table 11

The results of the rate of change in glucose changes in light exercise 20 minutes

Pairwise Comparisons ${ }^{b}$

Measure: Measure_1

\begin{tabular}{|c|c|c|c|c|}
\hline (I) Time & (J) Time & Mean Difference (I-J) & Std. Error & Sig. ${ }^{a}$ \\
\hline \multirow[t]{3}{*}{1} & 2 & $-55,200$ & 10,477 &, 001 \\
\hline & 3 & $-25,300$ & 6,389 & ,003 \\
\hline & 4 & $-13,200$ & 4,835 & ,023 \\
\hline \multirow[t]{2}{*}{2} & 3 & 29,900 & 8,031 & ,005 \\
\hline & 4 & 42,000 & 7,589 &, 000 \\
\hline 3 & 4 & 12,100 & 2,575 &, 001 \\
\hline
\end{tabular}

Based on estimated marginal means:

a. Adjustment for multiple comparisons: Least Significant

b. The difference (equivalent to no adjustments).

c. Group $=20$ Minutes Light Training

From the data above shows a very significant level of change (synaptic) from the difference in exercise 2 hours postprandial with 20 minutes after exercise $p=0.005$, the difference between 2 hours postprandial and 60 minutes after exercise $p=0.000$, the difference between 20 minutes after exercise with 60 minutes after practice $p=0.001$, 
all data above $\mathrm{p}<0.05$.

Table 12

Manova test results decrease blood sugar levels in moderate exercise 10 minutes. Multivariate Tests ${ }^{b, c}$

\begin{tabular}{lllllll}
\hline Effect & & Value & F & Hypothesis df & Error df & Sig. \\
\hline Waktu & Pillai's Trace &, 889 & $18,641^{\mathrm{a}}$ & 3,000 & 7,000 &, 001 \\
& Wilks'Lambda &, 111 & $18,641^{\mathrm{a}}$ & 3,000 & 7,000 &, 001 \\
& Hotelling's Trace & 7,989 & $18,641^{\mathrm{a}}$ & 3,000 & 7,000 &, 001 \\
& Roy's Largest Root & 7,989 & $18,641^{\mathrm{a}}$ & 3,000 & 7,000 &, 001 \\
\hline
\end{tabular}

a) Exact statistic

b) Design: Intercept

Within-Subjects Design: TIME c.

c) Group = 20 Minutes Light Training

From the data above shows that there is a significant value of $\mathrm{p}<0.05(\mathrm{p}=0.001)$ this means that there is a significant difference in the occurrence of changes in blood glucose in the treatment group.

Table 13

The results of the significant level of glucose changes in moderate latency of 10 minutes

Pairwise Comparisons ${ }^{b}$

Measure: Measure_1

\begin{tabular}{llrrr}
\hline (II) Time & $(\mathrm{J})$ Time & Mean Difference (I-J) & Std. Error & \multicolumn{1}{c}{ Sig. ${ }^{\text {a }}$} \\
\hline 1 & 2 & $-53,900$ & 8,189 &, 000 \\
& 3 & $-26,800$ & 6,270 &, 002 \\
& 4 & $-11,700$ & 1,732 &, 000 \\
2 & 3 & 27,100 & 3,926 &, 000 \\
& 4 & 42,200 & 6,859 &, 000 \\
3 & 4 & 15,100 & 4,927 &, 013 \\
\hline
\end{tabular}

Based on estimated marginal means:

a) Group = 20 Minutes Light Training

b) Adjustment for multiple comparisons: Least Significant Difference (equivalent to no adjustments).

From the data above, it can be seen that there is a very significant level of change (significant) from the difference in exercise 2 hours postprandial with 20 minutes after $\mathrm{p}=0,000$ practice, the difference between 2 hours postprandial and 60 minutes after exercise $\mathrm{p}=0,000$, the difference between 20 minutes after exercise with 60 minutes after practice $\mathrm{p}=0.013$, all the data above. From the data above, it can be seen that the level of change (synergy) is very significant because of $\mathrm{p}<0.05$.

Table 14

Average and SD data in the treatment group (descriptive statistics)

\begin{tabular}{|c|c|c|c|c|}
\hline & Group & Mean & Std. Deviation & $\mathrm{N}$ \\
\hline Reduction OF & Light Training 20 & & & \\
\hline \multirow[t]{3}{*}{ Faded 20} & Minutes & 29,9000 & 25,3966 & 10 \\
\hline & $\begin{array}{l}\text { Medium exercise } 10 \\
\text { minutes }\end{array}$ & 27,1000 & 12,4137 & 10 \\
\hline & Total & 28,5000 & 19,5084 & 20 \\
\hline Blood sugar & Light training 20 & & & \\
\hline \multirow[t]{2}{*}{ Reduction 60} & minutes & 42,0000 & 24,0000 & 10 \\
\hline & Medium exercise 10 & 42,2000 & 21,6887 & 10 \\
\hline
\end{tabular}

Fathoni, A., Adiputra, N., Pangkahila, J. A., \& Adiatmika, I. P. G. (2018). Reduction of levels postprandial blood glucose on medium intensity physical exercise in intervals and continues. International Research Journal of Engineering, IT \& Scientific Research, 4(6), 10-32. https://doi.org/10.21744/irjeis.v4n6.331 


\begin{tabular}{llll}
\hline minutes & & & \\
Total & 42,1000 & 22,2637 & 20 \\
\hline
\end{tabular}

From data above shows the average decrease in blood sugar difference between 2 hours postprandial with 20 minutes after light exercise duration of 20 minutes was $29.9000 \pm 25.3966 \mathrm{mg} / \mathrm{dl}$, the difference between 2 hours postprandial and 20 minutes after moderate exercise duration of 10 minutes was $27,1000 \pm 12,4137 \mathrm{mg} / \mathrm{dl}$. From the data above, the average blood sugar reduction difference between 2 hours postprandial and 60 minutes after 20 minutes of light exercise was $42,0000 \pm 24,0000 \mathrm{mg} / \mathrm{dl}$, the difference between 2 hours postprandial and 20 minutes after moderate exercise 10 minutes duration was $42,2000 \pm 21,6887 \mathrm{mg} / \mathrm{dl}$.

Table 15

Results of the level of change in the treatment group Multivariate Tests ${ }^{b}$

\begin{tabular}{lllllll}
\hline Effect & & Value & F & Hypothesis df & Error df & Sig. \\
\hline Time & Pillai's Trace &, 792 & $32,460^{\text {a }}$ & 2,000 & 17,000 &, 000 \\
& Wilks'Lambda &, 208 & $32,460^{\text {a }}$ & 2,000 & 17,000 &, 000 \\
& Hotelling's Trace & 3,819 & $32,460^{\text {a }}$ & 2,000 & 17,000 &, 000 \\
& Roy's Largest Root & 3,819 & $32,460^{\text {a }}$ & 2,000 & 17,000 &, 000 \\
GROUP & Pillai's Trace &, 020 &, $175^{\text {a }}$ & 2,000 & 17,000 &, 841 \\
& Wilks'Lambda &, 980 &, $175^{\text {a }}$ & 2,000 & 17,000 &, 841 \\
& Hotelling's Trace &, 021 &, $175^{\text {a }}$ & 2,000 & 17,000 &, 841 \\
& Roy's Largest Root &, 021 &, $175^{\text {a }}$ & 2,000 & 17,000 &, 841 \\
\hline
\end{tabular}

a) Exact statistic

b) Design: Intercept+KEL

From the data above the comparison between treatment groups to decrease blood glucose both in light intensity exercise duration of 20 minutes and moderate intensity, 10 minutes duration was the same, the difference was not too significant because value $\mathrm{p}>0.005(\mathrm{p}=0.841)$.

\subsection{Discussion}

Data obtained from the results of research in form of body weight of people trying $(\mathrm{kg})$, height $(\mathrm{cm})$ and fasting blood sugar levels (mg / dl), blood sugar 2 (two) hours postprandial, 20 after exercise (20 minutes postprandial), 10 minutes after exercise (10 minutes postprandial), 60 minutes after exercise in $\mathrm{mg} / \mathrm{dl}$. Data analysis was carried out with descriptive analysis, distribution normality test, homogeneity test, correlation test, and Manova test with a significance level of 5\% and all data processed with SPSS 10.0 program.

\section{Descriptive Data}

In this study, the data is taken included variables namely independent variables, dependent variables, and moderator variables. All of the data were analyzed statistically to obtain an overview of the distribution, summarization, and processing of data. The results of the descriptive analysis moderator variables can be seen in 5.1 and the dependent variable can be seen in table 5.2 below. The results of the analysis of the full variables can be seen in the attachment. 
Table 16

Average value and SD Variable BB (kg), TB (cm), Pulse (permanent) Report

\begin{tabular}{|c|c|c|c|c|c|c|}
\hline \multicolumn{4}{|l|}{ Group } & Weight body & Height Body & Pulse \\
\hline \multirow{3}{*}{$\begin{array}{l}\text { Light } \\
\text { minutes }\end{array}$} & Training & 20 & Mean & 49,20 & 163,40 & 86,50 \\
\hline & & & Std. Deviation & 4,47 & 4,33 & 1,96 \\
\hline & & & $\mathrm{N}$ & 10 & 10 & 10 \\
\hline \multirow{3}{*}{$\begin{array}{l}\text { Medium } \\
\text { minutes }\end{array}$} & training & 10 & Mean & 49,40 & 163,90 & 96,10 \\
\hline & & & Std. Deviation & 5,52 & 3,90 & 3,51 \\
\hline & & & $\mathrm{N}$ & 10 & 10 & 10 \\
\hline
\end{tabular}

From the data above the mean value for body weight and standard deviation in light training duration of 20 minutes

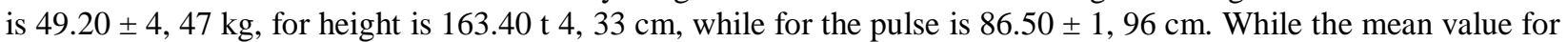
body weight at moderate exercise duration of 10 minutes is $49.40 \pm 5.52 \mathrm{~kg}$ for height $163.90 \pm 3.90 \mathrm{~cm}$ and for the pulse is $96.10 \pm 3.51$ per minute.

Table 17

Mean and SD variables for blood sugar $(\mathrm{mg} / \mathrm{dl})$ in all groups report

\begin{tabular}{|c|c|c|c|c|c|}
\hline \multicolumn{2}{|l|}{ Group } & $\begin{array}{l}\text { blood sugar } \\
\text { fasting }\end{array}$ & $\begin{array}{c}\text { blood sugar } \\
\text { J PP }\end{array}$ & $\begin{array}{l}\text { blood sugar } \\
20 \mathrm{M} \mathrm{PL}\end{array}$ & $\begin{array}{c}\text { blood sugar } \\
60 \mathrm{M} \mathrm{PL}\end{array}$ \\
\hline Light training & Mean & 145,10 & 200,30 & 170,40 & 158,30 \\
\hline minutes & Std. Deviation & 9,01 & 39,47 & 24,80 & 19,56 \\
\hline & $\mathrm{N}$ & 10 & 10 & 10 & 10 \\
\hline Medium training 10 & Mean & 149,00 & 202,90 & 175,80 & 160,70 \\
\hline minutes & Std. Deviation & 11,07 & 34,20 & 26,08 & 15,00 \\
\hline & $\mathrm{N}$ & 10 & 10 & 10 & 10 \\
\hline
\end{tabular}

From the data above in light intensity training for 20 minutes, the mean of fasting blood mean $145.10 \pm 9.01 \mathrm{mg} / \mathrm{dl}$, blood sugar 2 hours post prandial $200.30 \pm 39.47 \mathrm{mg} / \mathrm{dl}$, blood sugar 20 minutes after exercise was $170.40 \pm 24.80$ $\mathrm{mg} / \mathrm{dl}$, blood sugar 60 minutes after exercise $158.30 \pm 19.56 \mathrm{mg} / \mathrm{dl}$. From the data above on 10-minutes medium intensity exercise, the mean fasting blood sugar was $149.00 \pm 11.07 \mathrm{mg} / \mathrm{dl}$, blood sugar 2 hours postprandial was $202.30 \pm 34.20 \mathrm{mg} / \mathrm{dl}$, blood sugar 20 minutes after exercise of $175.80 \pm 26.08 \mathrm{mg} / \mathrm{dl}$, blood sugar 60 minutes after exercise amounted to $160.70 \pm 15.00 \mathrm{mg} / \mathrm{dl}$.

Table 18

Average value and SD Variable BB $(\mathrm{kg}), \mathrm{TB}(\mathrm{cm})$, Pulse (permanent) Report

\begin{tabular}{|c|c|c|c|c|}
\hline \multicolumn{2}{|l|}{ Group } & $\begin{array}{c}\text { Decrease in blood } \\
\text { sugar-20 }\end{array}$ & $\begin{array}{c}\text { Decrease in blood } \\
\text { sugar- } 60\end{array}$ & $\begin{array}{c}\text { Decrease in blood } \\
\text { sugar-20-60 }\end{array}$ \\
\hline Light training 20 & Mean & 29,9000 & 42,0000 & 12,1000 \\
\hline minutes & Std. Deviation & 25,3966 & 24,0000 & 8,1438 \\
\hline & $\mathrm{N}$ & 10 & 10 & 10 \\
\hline Medium training & Mean & 27,1000 & 42,2000 & 15,1000 \\
\hline 10 minutes & Std. Deviation & 12,4137 & 21,6887 & 15,5810 \\
\hline & $\mathrm{N}$ & 10 & 10 & 10 \\
\hline
\end{tabular}

From the data above 20 minutes of light physical exercise, the average blood glucose reduction difference between 2 hours postprandial and 20 minutes after exercise was $29.9000 \pm 25.3966 \mathrm{mg} / \mathrm{dl}$, the mean blood glucose reduction difference between 2 hours postprandial and 60 minutes after exercise was 42,0000 $\pm 24,000 \mathrm{mg} / \mathrm{dl}$, the mean decrease in blood glucose difference between 20 minutes after exercise with 60 minutes after exercise was $12,1000 \pm$ $8,1438 \mathrm{mg} / \mathrm{dl}$. From the above data on a 10 -minute moderate intensity physical exercise, the average blood glucose reduction difference between 2 hours postprandial and 20 minutes after exercise was $27.1000 \pm 12.4137 \mathrm{mg} / \mathrm{dl}$, the

Fathoni, A., Adiputra, N., Pangkahila, J. A., \& Adiatmika, I. P. G. (2018). Reduction of levels postprandial blood glucose on medium intensity physical exercise in intervals and continues. International Research Journal of Engineering, IT \& Scientific Research, 4(6), 10-32. https://doi.org/10.21744/irjeis.v4n6.331 
mean blood glucose reduction difference between 2 hours postprandial and 60 minutes after exercise was $42.2000 \pm$ $21.6887 \mathrm{mg} / \mathrm{dl}$, the average decrease in blood glucose difference between 20 minutes after exercise with 60 minutes after exercise was $15.1000 \pm 15.5810 \mathrm{mg} / \mathrm{dl}$.

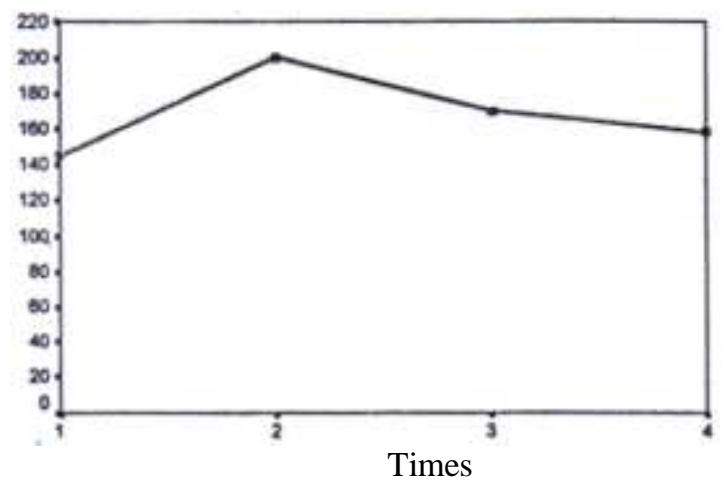

Figure 5. Graph of decreased blood glucose in moderate exercise group duration of 20 minutes (Blood Sugar Action, Group: 1, Light Exercise 20 Minutes)

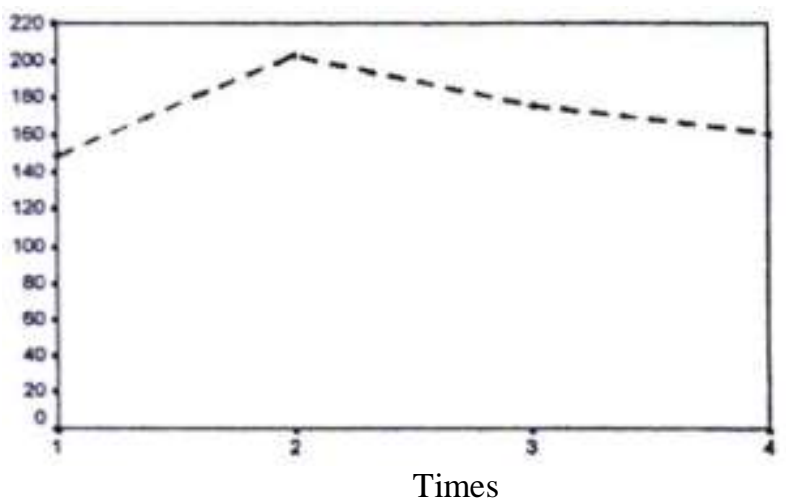

Figure 6. Graph of decreased blood glucose in moderate exercise group duration of 10 minutes (Blood Sugar Action, Group 2, Medical Training 10 Minutes)

\section{Normality Test}

To find out whether the data to be analyzed is normally distributed or not to determine to the next statistical test stage, normality tests are carried out. The results of the Kolmogorov-Smirnov normality test were carried out in the treatment group, namely the group on 20 minutes of light intensity physical exercise with 10 minutes of moderate intensity physical exercise which referred to the price value of $p>0.05$ means normal distribution.

Table 19

Test the normality of blood sugar values in the 20-minute light exercise group.

One-sample Kolmogorov-Smirnov Test ${ }^{\mathrm{C}}$

\begin{tabular}{llrrrr}
\hline & & \multirow{2}{*}{ Faded } & Faded 2 J PP & Faded 20 M & \multicolumn{2}{c}{ Faded 60 M } \\
& & & & \multicolumn{2}{c}{ PL } \\
\hline N Normal Parameters & & 10 & 10 & 10 & 10 \\
& Mean & 145,10 & 200,30 & 170,40 & 158,30 \\
Most Extreme & Std. Deviation & 9,01 & 39,47 & 24,80 & 19,56 \\
Differences & Absolute &, 204 &, 203 &, 248 &, 201 \\
& Positive &, 204 &, 203 &, 248 &, 201 \\
& Negative &,- 115 &,- 142 &,- 173 &,- 138 \\
\hline
\end{tabular}




Kolmogorop_Smirnov Z
Asymp. Sig. (2-tailed)
a) Test distribution is Normal.
b) Calculated from data.
c) Group = 20 Minutes Light Training

From the data above shows that the normality test for fasting blood sugar $(\mathrm{p}=0.797)$, blood sugar 2 hours postprandial $(\mathrm{p}=0.804)$, blood sugar 20 minutes after exercise $(\mathrm{p}=0.572)$ and 60 minutes $(\mathrm{p}=0.815)$ and see the significant value which refers to $\mathrm{p}>0.05$ then the data above is normally distributed.

Table 20

Normality value test decreased blood sugar in the 20-minute light exercise group.

One-sample Kolmogorov-Smirnov Test

\begin{tabular}{|c|c|c|c|c|}
\hline & & $\begin{array}{c}\text { Reduction of } \\
\text { blood sugar-20 }\end{array}$ & $\begin{array}{c}\text { Reduction of } \\
\text { blood sugar- } 60\end{array}$ & $\begin{array}{c}\text { Reduction of } \\
\text { blood sugar20-60 }\end{array}$ \\
\hline $\mathrm{N}$ & & 10 & 10 & 10 \\
\hline \multirow[t]{2}{*}{ Normal Parameters } & Mean & 29,9000 & 42,0000 & 12,1000 \\
\hline & Std. Deviation & 25,3966 & 24,0000 & 8,1438 \\
\hline Most Extreme & Absolute & ,290 & ,317 & ,202 \\
\hline \multirow[t]{2}{*}{ Differences } & Positive & ,290 & ,317 & ,202 \\
\hline & Negative &,- 228 &,- 191 &,- 132 \\
\hline Kolmogorop_Smirnov Z & & ,917 & 1,004 & ,638 \\
\hline Asymp. Sig. (2-tailed) & & 370 & ,266 &, 810 \\
\hline
\end{tabular}
a) Test distribution is Normal
b) Calculated from data
c) Group = 20 minutes light training

From the above data on light intensity physical exercise for 20 minutes, the average blood glucose reduction difference between 2 hours postprandial and 20 minutes after exercise was $29.9000 \pm 25.3966 \mathrm{mg} / \mathrm{dl}$, the average blood glucose reduction difference between 2 hours postprandial and 60 minutes after exercise was 42,0000 \pm $24,0000 \mathrm{mg} / \mathrm{dl}$, the mean reduction in blood glucose difference between 20 minutes after exercise with 60 minutes after exercise was $12,1000 \pm 8,1438 \mathrm{mgl}$, and saw the significant value referring to $\mathrm{p}>0 \mathrm{05}$, the data above is normally distributed.

Table 21

The normality test of blood sugar values in the moderate exercise group was 20 minutes One-sample Kolmogorov-Smirnov Test ${ }^{\mathrm{C}}$

\begin{tabular}{|c|c|c|c|c|c|}
\hline & & Blood sugar & $\begin{array}{c}\text { Blood sugar } \\
2\end{array}$ & $\begin{array}{l}\text { Blood sugar } \\
20 \mathrm{M} \mathrm{PL}\end{array}$ & $\begin{array}{c}\text { Blood sugar } \\
60 \mathrm{M} \mathrm{PL}\end{array}$ \\
\hline $\mathrm{N}$ & & 10 & 10 & 10 & 10 \\
\hline \multirow[t]{2}{*}{ Normal Parameters } & Mean & 149,00 & 202,90 & 175,80 & 160,70 \\
\hline & Std. Deviation & 11,07 & 34,20 & 26,08 & 15,00 \\
\hline Most Extreme & Absolute &, 128 & ,334 & ,306 & ,219 \\
\hline \multirow{2}{*}{ Differences } & Positive &, 128 & ,334 & ,306 & ,219 \\
\hline & Negative &,- 126 &,- 183 &,- 272 &,- 112 \\
\hline Kolmogorop_Smirnov Z & & ,406 & 1,056 & ,968 & ,691 \\
\hline Asymp. Sig. (2-tailed) & & 997 &, 215 & ,306 & ,726 \\
\hline
\end{tabular}

a) Test distribution is Normal.

b) Calculated from data.

c) Group = 20 Minutes Light Training

Fathoni, A., Adiputra, N., Pangkahila, J. A., \& Adiatmika, I. P. G. (2018). Reduction of levels postprandial blood glucose on medium intensity physical exercise in intervals and continues. International Research Journal of Engineering, IT \& Scientific Research, 4(6), 10-32. https://doi.org/10.21744/irjeis.v4n6.331 
From the data above shows that the normality test for fasting blood sugar $(\mathrm{p}=0.997)$, blood sugar 2 hours postprandial $(p=0.215)$, blood sugar 20 minutes after exercise $(p=0.306)$ and 60 minutes after exercise $(p=0.726)$ and see the significant value which refers to $p>0.05$ then the data above is normally distributed.

Table 22

The normality test of blood sugar values in the moderate exercise group was 20 minutes. One-sample Kolmogorov-Smirnov Test ${ }^{\mathrm{C}}$

\begin{tabular}{|c|c|c|c|c|}
\hline & & $\begin{array}{c}\text { Decrease in } \\
\text { blood sugar-20 }\end{array}$ & $\begin{array}{c}\text { Decrease in } \\
\text { blood sugar- } 60\end{array}$ & $\begin{array}{l}\text { Decrease in blood } \\
\text { sugar-20-60 }\end{array}$ \\
\hline $\mathrm{N}$ & & 10 & 10 & 10 \\
\hline \multirow[t]{2}{*}{ Normal Parameters } & Mean & 27,1000 & 42,2000 & 15,1000 \\
\hline & Std. Deviation & 12,4137 & 21,6887 & 15,5810 \\
\hline Most Extreme & Absolute &, 113 &, 313 & ,238 \\
\hline \multirow[t]{2}{*}{ Differences } & Positive &, 108 & 313 & 229 \\
\hline & Negative &,- 113 &,- 228 &,- 238 \\
\hline Kolmogorop_Smirnov Z & & 358 & ,988 &, 756 \\
\hline Asymp. Sig. (2-tailed) & & 1,000 & 283 & ,622 \\
\hline
\end{tabular}

a) Test distribution is Normal.

b) Calculated from data.

c) Group $=10$ Minutes Light Training

From the above data on moderate intensity physical exercise 10 minutes duration seen significant values of blood glucose reduction difference between 2 hours postprandial with 20 minutes after exercise $(p=1,000)$, significant value of blood glucose reduction difference between 2 hours postprandial with 60 minutes after exercise $(\mathrm{p}=0.283)$, a significant value of blood glucose deposition difference between 20 minutes after exercise with 60 minutes after exercise $(p=0.622)$ and seeing the significant value referring to $p>0.05$, the data above is normally distributed.

\section{Homogeneity Test}

Homogeneity test is carried out to find out that the variance in the initial conditions will occur after differences in exercise or treatment.

Table 23

Homogeneity Test ANOVA Table

\begin{tabular}{llccccc}
\hline & Sum Of Squares & Df & Mean Square & F & Sig. \\
\hline Weight body & Between Groups & 200 & 1 & 200 & .008 & .930 \\
& Within Groups & 454.000 & 18 & 25.222 & & \\
& Total & 454.200 & 19 & & & \\
Height body & Between Groups & 1.250 & 1 & 1.250 & .074 & .789 \\
& Within Groups & 305.300 & 18 & 16.961 & & \\
& Total & 306.550 & 19 & & & \\
& Between Groups & 460.800 & 1 & 460.800 & 57.045 & .000 \\
& Within Groups & 145.400 & 18 & 8.078 & & \\
& Total & 606.200 & 19 & & & \\
\hline
\end{tabular}

From the data above, it can be seen that the weight homogeneity $(\mathrm{p}=0.930)$, height $(\mathrm{P}=0.789) \mathrm{p}$-value is greater than 0.05 , the data above includes homogeneous data. 


\section{Test of Difference in Changes in Blood Glucose}

The test results of different changes in blood glucose levels, is in a group of light intensity duration of 20 minutes and medium intensity duration of 10 minutes.

Table 24

Average data and SD Blood glucose training is 20 minutes light (descriptive statistics)

\begin{tabular}{lccc}
\hline & Mean & Std. Deviation & $\mathrm{N}$ \\
\hline Fasting blood sugar & 145,10 & 9,01 & 10 \\
Fasting blood sugar 2 J & 200,30 & 39,47 & 10 \\
PP & & & 10 \\
$\begin{array}{l}\text { Fasting blood sugar20 M } \\
\text { PL }\end{array}$ & 170,40 & 24,80 & 10 \\
$\begin{array}{l}\text { Fasting blood sugar 60 } \\
\text { M PL }\end{array}$ & 158,30 & 19,56 & \\
\hline
\end{tabular}

From the data above, it can be seen that the mean fasting blood sugar value in light exercise of 20 minutes duration is $145.10 \pm 9.01 \mathrm{mg} / \mathrm{dl}$, blood sugar 2 hours postprandia1 $200.30 \pm 39.47 \mathrm{mg} / \mathrm{dl}$, blood sugar 20 minutes after exercise $170,40 \pm 24.80 \mathrm{mg} / \mathrm{dl}$, blood sugar 60 minutes after exercise $158.30 \pm 19.6 \mathrm{mg} / \mathrm{dl}$.

Table 25

Manova test results decrease blood sugar levels in 20 minutes light exercise (multivariate tests)

\begin{tabular}{lllllll}
\hline Effect & & Value & F & Hypothesis df & Error df & Sig. \\
\hline Time & Pillai's Trace &, 863 & $14,661^{\mathrm{a}}$ & 3,000 & 7,000 &, 002 \\
& Wilks'Lambda &, 137 & $14,661^{\mathrm{a}}$ & 3,000 & 7,000 &, 002 \\
& Hotelling's Trace & 6,283 & $14,661^{\mathrm{a}}$ & 3,000 & 7,000 &, 002 \\
& Roy's Largest Root & 6,283 & $14,661^{\mathrm{a}}$ & 3,000 & 7,000 &, 002 \\
\hline
\end{tabular}
a) Exact statistic
b) Design: Intercept
Within-Subjects Design: Time
c) Group $=20$ Minutes Light Training

From the data above shows that there is a significant value of $p<0.05(\mathrm{p}=0.002)$ this means that there is a significant difference in the occurrence of changes in blood glucose in the treatment group.

Table 26

The results of the rate of change in glucose changes in light exercise 20 minutes Pairwise Comparisons ${ }^{b}$

Measure: Measure_1

\begin{tabular}{|c|c|c|c|c|c|}
\hline (III) & Time & (J) Time & Mean Difference (I-J) & Std. Error & Sig. ${ }^{a}$ \\
\hline \multirow[t]{3}{*}{1} & & 2 & $-55,200$ & 10,477 &, 001 \\
\hline & & 3 & $-25,300$ & 6,389 &, 003 \\
\hline & & 4 & $-13,200$ & 4,835 & ,023 \\
\hline \multirow[t]{2}{*}{2} & & 3 & 29,900 & 8,031 &, 005 \\
\hline & & 4 & 42,000 & 7,589 &, 000 \\
\hline 3 & & 4 & 12,100 & 2,575 &, 001 \\
\hline
\end{tabular}

Based on estimated marginal means:

a) Adjustment for multiple comparisons: Least Significant

b) Difference (equivalent to no adjustments).

Fathoni, A., Adiputra, N., Pangkahila, J. A., \& Adiatmika, I. P. G. (2018). Reduction of levels postprandial blood glucose on medium intensity physical exercise in intervals and continues. International Research Journal of Engineering, IT \& Scientific Research, 4(6), 10-32. https://doi.org/10.21744/irjeis.v4n6.331 


\section{c) Group = 20 Minutes Light Training}

From the data above shows a very significant level of change (synaptic) from the difference in exercise 2 hours postprandial with 20 minutes after exercise $p=0.005$, the difference between 2 hours postprandial and 60 minutes after exercise $\mathrm{p}=0.000$, the difference between 20 minutes after exercise with 60 minutes after practice $\mathrm{p}=0.001$, all data above $\mathrm{p}<0.05$.

Table 27

Manova test results decrease blood sugar levels in moderate exercise 10 minutes. Multivariate Tests ${ }^{b, c}$

\begin{tabular}{lllllll}
\hline Effect & & Value & F & Hypothesis df & Error df & Sig. \\
\hline Waktu & Pillai's Trace &, 889 & $18,641^{\mathrm{a}}$ & 3,000 & 7,000 &, 001 \\
& Wilks'Lambda &, 111 & $18,641^{\mathrm{a}}$ & 3,000 & 7,000 &, 001 \\
& Hotelling's Trace & 7,989 & $18,641^{\mathrm{a}}$ & 3,000 & 7,000 &, 001 \\
& Roy's Largest Root & 7,989 & $18,641^{\mathrm{a}}$ & 3,000 & 7,000 &, 001 \\
\hline
\end{tabular}

a) Exact statistic

b) Design: Intercept

Within-Subjects Design: TIME c.

c) Group = 20 Minutes Light Training

From the data above shows that there is a significant value of $\mathrm{p}<0.05(\mathrm{p}=0.001)$ this means that there is a significant difference in the occurrence of changes in blood glucose in the treatment group.

Table 28

The results of the significant level of glucose changes in moderate latency of 10 minutes Pairwise Comparisons ${ }^{b}$

\begin{tabular}{|c|c|c|c|c|c|}
\hline (IV) & Time & (J) Time & Mean Difference (I-J) & Std. Error & Sig. ${ }^{a}$ \\
\hline \multirow[t]{3}{*}{1} & & 2 & $-53,900$ & 8,189 &, 000 \\
\hline & & 3 & $-26,800$ & 6,270 &, 002 \\
\hline & & 4 & $-11,700$ & 1,732 &, 000 \\
\hline \multirow[t]{2}{*}{2} & & 3 & 27,100 & 3,926 &, 000 \\
\hline & & 4 & 42,200 & 6,859 & ,000 \\
\hline 3 & & 4 & 15,100 & 4,927 &, 013 \\
\hline
\end{tabular}

Based on estimated marginal means:

a) Adjustment for multiple comparisons: Least Significant Difference (equivalent to no adjustments).

b) Group = 20 Minutes Light Training

From the data above, it can be seen that there is a very significant level of change (significant) from the difference in exercise 2 hours postprandial with 20 minutes after $\mathrm{p}=0,000$ practice, the difference between 2 hours postprandial and 60 minutes after exercise $p=0,000$, the difference between 20 minutes after exercise with 60 minutes after practice $\mathrm{p}=0.013$, all the data above. From the data above, it can be seen that the level of change (synergy) is very significant because of $\mathrm{p}<0.05$. 
Table 29

Average and SD data in the treatment group (descriptive statistics)

\begin{tabular}{llccr}
\hline & Group & Mean & Std. Deviation & N \\
\hline $\begin{array}{l}\text { Reduction of } \\
\text { Faded 20 }\end{array}$ & $\begin{array}{l}\text { Light training 20 } \\
\text { minutes }\end{array}$ & 29,9000 & 25,3966 & 10 \\
& $\begin{array}{l}\text { Medium exercise 10 } \\
\text { minutes }\end{array}$ & 27,1000 & 12,4137 & 10 \\
& Total & 28,5000 & 19,5084 & 20 \\
Blood sugar & Light training 20 & & & \\
Reduction 60 & minutes & 42,0000 & 24,0000 & 10 \\
& Medium exercise 10 & 42,2000 & 21,6887 & 10 \\
& minutes & 42,1000 & 22,2637 & 20 \\
\hline
\end{tabular}

From data above shows the average decrease in blood sugar difference between 2 hours postprandial with 20 minutes after light exercise duration of 20 minutes was $29.9000 \pm 25.3966 \mathrm{mg} / \mathrm{dl}$, the difference between 2 hours postprandial and 20 minutes after moderate exercise duration of 10 minutes was $27,1000 \pm 12,4137 \mathrm{mg} / \mathrm{dl}$. From the data above, the average blood sugar reduction difference between 2 hours postprandial and 60 minutes after 20 minutes of light exercise was $42,0000 \pm 24,0000 \mathrm{mg} / \mathrm{dl}$, the difference between 2 hours postprandial and 20 minutes after moderate exercise 10 minutes duration was 42, $2000 \pm 21,6887 \mathrm{mg} / \mathrm{dl}$.

Table 30

Results of the level of change in the treatment group Multivariate Tests ${ }^{\mathrm{b}}$

\begin{tabular}{lllllll}
\hline Effect & & Value & F & Hypothesis df & Error df & Sig. \\
\hline Time & Pillai's Trace &, 792 & $32,460^{\text {a }}$ & 2,000 & 17,000 &, 000 \\
& Wilks'Lambda &, 208 & $32,460^{\text {a }}$ & 2,000 & 17,000 &, 000 \\
& Hotelling's Trace & 3,819 & $32,460^{\text {a }}$ & 2,000 & 17,000 &, 000 \\
& Roy's Largest Root & 3,819 & $32,460^{\text {a }}$ & 2,000 & 17,000 &, 000 \\
GROUP & Pillai's Trace &, 020 &, $175^{\text {a }}$ & 2,000 & 17,000 &, 841 \\
& Wilks'Lambda &, 980 &, $175^{\text {a }}$ & 2,000 & 17,000 &, 841 \\
& Hotelling's Trace &, 021 &, $175^{\text {a }}$ & 2,000 & 17,000 &, 841 \\
& Roy's Largest Root &, 021 &, $175^{\text {a }}$ & 2,000 & 17,000 &, 841 \\
\hline
\end{tabular}

a. Exact statistic

b. Design: Intercept+KEL

From the data above the comparison between treatment groups to decrease blood glucose both in light intensity exercise duration of 20 minutes and moderate intensity, 10 minutes duration was the same, the difference was not too significant because value $\mathrm{p}>0.005(\mathrm{p}=0.841)$.

Suggestion

Although this study can provide additional scientific information on the effect of 20 minutes duration of light intensity physical exercise and 10 minutes of moderate intensity on decreasing postprandial blood glucose levels, there are still many studies that need to be done to expand the theoretical explanation and its application - among others research on load determination exercise, and research on the risk group of people with diabetes mellitus.

Fathoni, A., Adiputra, N., Pangkahila, J. A., \& Adiatmika, I. P. G. (2018). Reduction of levels postprandial blood glucose on medium intensity physical exercise in intervals and continues. International Research Journal of Engineering, IT \& Scientific Research, 4(6), 10-32. https://doi.org/10.21744/irjeis.v4n6.331 


\section{Conclusion}

From the discussion described earlier, the following conclusions can be drawn included (1) Light intensity physical exercise for 20 minutes can reduce blood glucose in diabetes mellitus patients immediately after exercise and 1 hour after exercise. (2) 10 minutes of moderate intensity physical exercise can reduce blood glucose immediately after 10 minutes of exercise and 1 hour after exercise. (3) There is no difference in blood glucose reduction in 20 minutes duration light exercise with 10 minutes duration exercise in people with diabetes mellitus.

\section{Conflict of interest statement and funding sources}

The author declared that he has no competing interest. The study was financed by personal funding.

Statement of authorship

The author has a responsibility for the conception and design of the study. The author has approved the final article.

\section{Acknowledgments}

The author would like to thank the reviewer for their consideration to the further process of the peer review. The author as well as thanks to the editor for their support, valuable time, and advice. Last but not least, the author thanks all researcher for their contribution as the references to the present article. 


\section{References}

Blevins, J. E., Dixon, K. D., Hernandez, E. J., Barrett, J. A., \& Gietzen, D. W. (2000). Effects of threonine injections in the lateral hypothalamus on intake of amino acid imbalanced diets in rats. Brain research, 879(1-2), 65-72.

Brooks, G. A. (2011). Bioenergetics of exercising humans. Comprehensive Physiology, 2(1), 537-562.

Cantu, R. C. (Ed.). (1987). The exercising adult. New York: Macmillan.

Fox, E. L., Bowers, R. W., \& Foss, M. L. (1993). The physiological basis for exercise and sport (No. Ed. 5). Brown \& Benchmark.

Fox, S. I. (1999). Physiology of the kidney. Human Physiology, 528.

Goodyer, I. D., Jones, E. E., Monaco, A. P., \& Francis, M. J. (1999). Characterization of the Menkes protein copperbinding domains and their role in copper-induced protein relocalization. Human molecular genetics, 8(8), 14731478.

Higgins, J. E., \& Kleinbaum, A. P. (1985). Introduction To Randomized Clinical Trials. Part 1 of the series: The Basics of Randomized Clinical Trials with an Emphasis on Contraceptive Research. USA. Family Health International. Research Trangle Park, North Caroline, 27709, 25-30.

Janssen, A. M., Scheffer, J. J. C., \& Svendsen, A. B. (1987). Antimicrobial activity of essential oils: A 1976-1986 literature review. Aspects of the test methods. Planta medica, 53(05), 395-398.

Leaf, A., \& Weber, P. C. (1988). Cardiovascular effects of n-3 fatty acids. New England Journal of Medicine, 318(9), 549-557.

Noble, B. J. (1986). Physiology of exercise and sport (No. 747). Times Mirror Magazine.

Nuriyasa, I. M., Puspani, E., \& Yupardhi, W. S. (2018). Growth and Blood Profile of Lepus Nigricollis Fed Diet Fermented Coffee Skin in Different Levels. International Journal of Life Sciences (IJLS), 2(1), 21-28.

Saltin, B. (1968). Response to exercise after bed rest and after training. Circulation, 38, 1-78.

Soeparman, S. W. (1991). Ilmu Penyakit Dalam Jilid II Edisi I. Jakarta: Gaya Baru, 3-6.

Taylor, B. N., Parker, W. H., \& Langenberg, D. N. (1969). Determination of e h, using macroscopic quantum phase coherence in superconductors: Implications for quantum electrodynamics and the fundamental physical constants. Reviews of Modern Physics, 41(3), 375.

Wilmore, J. H., \& Costill, D. L. (1994). Physiology of exercise and sport. Champaign, IL: Human Kinetics.

Wiryawan, A. (2000). Use of flow injection analysis for continuous monitoring of river water quality. Laboratory Robotics and Automation, 12(3), 142-148.

Yaspelkis 3rd, B. B., Patterson, J. G., Anderla, P. A., Ding, Z., \& Ivy, J. L. (1993). Carbohydrate supplementation spares muscle glycogen during variable-intensity exercise. Journal of Applied Physiology, 75(4), 1477-1485.

Youngren, J. F. (2003). Exercise and the regulation of blood glucose. Endotext. org: Diabetes and Carbohydrate Metabolism. 1st ed. Internet-based: http://www. mdtext. com, 3.

Zainudin, M., Razak, M., \& Shukur, S. H. (2000). Clinical experience with reamed locked nails for close and open comminuted tibial diaphyseal fractures: a review of 50 consecutive cases. The Medical journal of Malaysia, 55 , 59-67.

Fathoni, A., Adiputra, N., Pangkahila, J. A., \& Adiatmika, I. P. G. (2018). Reduction of levels postprandial blood glucose on medium intensity physical exercise in intervals and continues. International Research Journal of Engineering, IT \& Scientific Research, 4(6), 10-32. https://doi.org/10.21744/irjeis.v4n6.331 


\section{Biography of Authors}

\begin{tabular}{|l|l|}
\hline \hline & $\begin{array}{l}\text { Akhmad Fathoni, SKp., M.Kes. was born in Mendagi August 13 }{ }^{\text {th }}, 1972 . \text { He graduated } \\
\text { his bachelor degree in nursing department at Indonesia University in 1999. He finished } \\
\text { his master degree in basic medical sciences in sociology specialization at Airlangga } \\
\text { University, Surabaya in 2006. He currently a doctoral student in the doctoral program } \\
\text { of Udayana University, medical science studies program, sports physiology. He } \\
\text { interested in the field study included Anatomy of physiology, pathophysiology, } \\
\text { biochemistry, pathology, and surgical medical nursing. He works in POLTEKKES } \\
\text { KEMENKES Mataram at Jln. Prabu Rangkasari Dasan Cermin Mataram Ph. +62370 } \\
\text { 631160, Fax. +62370 621383 Email: afathoni72@gmail.com }\end{array}$ \\
\hline
\end{tabular}

